\title{
Correction to: Crossing Border in the European Railway System: Operating Modes Management by Colored Petri Nets
}

Hela Kadri, Simon Collart-Dutilleul, and Philippe Bon

\section{Correction to:}

Chapter 8 in: S. Collart-Dutilleul (ed.), Operating Rules and Interoperability in Trans-National High-Speed Rail, https://doi.org/10.1007/978-3-030-72003-2_8

This book was inadvertently published with incorrect University name in the affiliation of Dr. Hela Kadri in Chapter 8.

The affiliation has been updated as follows:

Université de Lille, Laboratoire Cristale, Lille, France 